\title{
Realistic Mathematic Education (RME) Model in Primary School
}

\author{
Gamar Al Haddar ${ }^{1}$, Desi Novi Al Safitri ${ }^{2}$ Arbain $^{3}$ \\ \{gamar@uwgm.ac.id ${ }^{1}$,desinovi606@gmail.com ${ }^{2}$, arbain1301@gmail.com ${ }^{3}$ \} \\ ${ }^{1,2,3}$ Widya Gama Mahakam University
}

\begin{abstract}
This research aims to improve students'achievement in mathematic by applying model of Realistic Mathematic Education (RME). A classroom action research was conducted in responding this issue by involving 36 students. This study applied four stages; planning, implementation, observation and reflection. This research use test, observation, interview, documentation and triangulation to collect the data. This research use combination data analysis techniques (mixed method) to analyze the data. The research result shows that the implementation of realistic mathematic education model was effective to improve students' achievement in mathematic. The progress can be seen in percentage of students' average score in each cycle. At cycle 1, students' average was 70 and 64\% students were able to reach the passing grade. Meanwhile, at cycle 2, the average score increased into 81 with $92 \%$ students achieved the passing grade. In addition, at cycle 3 , students'average score was 86 with $94 \%$ students accomplished the passing grade.
\end{abstract}

Keywords: Students' Achievement, Mathematic, Model of Realistic Mathematic Education

\section{Introduction}

People can get education through formal, informal and non-formal education. Formal education in Indonesia consists of Primary School, Intermediate School and Higher Education. The people of Indonesia are required to study through the program of 9-year Compulsory Education, which is one of efforts to improve education in Indonesia. The successful education is also affected by a number of factors. These factors include: students, curriculum, education employees, education cost and infrastructure, and environment factors.

Education cannot be separated from the word 'learning', for learning is a part of education. Learning can be defined as a step of changing of all of individual behaviors which is relatively preserved, through experience and interaction with environment, in which involves 3 aspects consisting of cognitive, affective and psychomotor [1]. Learning is also a process of individual behavior change due to interaction with environment.

Primary school is one of main education stages, which plays a role as the foundation in instilling basic knowledge for the next stages of education. In the stage of primary school, students are taught a number of subjects, one of which is mathematic[2]. 
Mathematic is a very important subject in several disciplines and in daily life. In mathematics, a person is demanded to possess the capability in logical, analytical, systematic, critical and creative thinking, as well as the ability in cooperation. Therefore, mathematics is also taught in all stages of education, ranging from primary school to higher education[3].

Mathematics, especially in primary school, is a very important subject that the allocated time for the subject is more than other subjects. The purpose of the subject of mathematics in primary school is to give students the capabilities of: (1) understanding mathematical concepts, (2) using reasoning on patterns and characteristics, developing proofs, explaining ideas and mathematical statements, (3) solving problems involving the abilities in understanding problems, designing mathematical models and interpreting the solution obtained, (4) communicating idea in numbers to clarify a situation, (5) appreciating the use of mathematics in life, i.e. possessing curiosity, paying attention and putting interest in mathematics, as well as possessing tenacious attitude and confidence in problem solving [4].

Students' understanding in every learning material of mathematics is very important. One of mathematics material is data processing. The data processing material is very important for students to learn because it contains the discussion regarding how to collect and read data, how to process and present data, in which students can present the data in forms of tables and charts, and by which students can read and interpret data.

The reality in the field shows that most of 4th graders in SDN 001 Sungai Kunjang have not fully understood the concept of data processing; this is due to lack of students' ability in grasping the explanation presented by their teacher, which leads to students' low scores, and students' perception that Mathematics materials are hard to understand.

According to the result of observation on teacher during the teaching, the teacher preferred speech method over other methods of teaching. During the course of learning process, the teacher asked the students to do the exercise in their textbook. During the learning process, students did not pay a good attention, played around and chat with their seatmates. The teacher often gave a warning, but the students only paid a momentary attention, just before they repeat the mistakes over and over again. From those problems, it can be stated that efforts in improving the learning process is required, and one of the efforts that can be done is by using the Model of Realistic Mathematic Education (RME).

RME is a model with an approach which gives the students an opportunity to apply the existing mathematical concepts to solve problems in daily life or other fields of subjects. Through

Realistic Mathematic Education (RME) learning, the process of learning will be enjoyable. The students are the ones involved more actively in the learning process to solve problems in mathematics [5]. From above background of study, the researchers are interested in conducting research regarding 'Improvement on Mathematics Learning Results of 5th Graders in SDN 001 Sungai Kunjang with Realistic Mathematic Education Model'.

\section{Finding and Discussion}

The research is an Action Classroom Research conducted with 3 cycles, which was conducted on from April to May of 2018. In every cycle, 3 meetings were conducted. In every cycle 4 continuous steps were involved i.e. planning, implementation, observation and reflection [6]. The 
subject of the research was 4th Graders in Room A, with a total of 36 students. The result of the research is described as follow:

\subsection{Cycle I}

The first cycle was conducted with 3 meetings in every learning process. The cycle was conducted on April $21^{\text {st }}$, April $25^{\text {th }}$, and April $26^{\text {th }}$ of 2018. The process of conducting the cycle is described as follow:

In the planning step of Cycle I, the researchers developed a Lesson Plan in the discussion of collecting, presenting and reading data in a form of bar charts. The researchers also prepared student observation sheets to evaluate classroom learning process [7]. The researchers also prepared learning media in a form of a measuring tape, to be used in the teaching process.

In the step of implementation[8], the researchers explained about how to present data into a bar chart and how to read it, and then the researchers divided the class into 6 groups, which each group consisted of 6 students. The researchers then, asked students to measure the height of each student with the media of measuring tape provided and explained the working instructions to the student. At the end of Cycle I, the researchers distributed the final test exercise sheets to students. The average score obtained was 70 , with 23 students passed the test, representing the percentage of $64 \%$ of total students; and 13 students failed the test, representing $36 \%$ of total students.

The observation of students learning activity in cycle I is described as follow: Students who actively asked questions regarding the discussion and did the exercise comprised of $71 \%$ total students; students who behaved well during the learning process comprised of $73 \%$; students who kept good interactions with classmates and teacher represented $70 \%$ of total students; and students with good accuracy in doing the exercise given by teacher constitute $68 \%$ of total students.

According to the data description of Cycle I, the result can be explained as follow: There were still several students who were rowdy and hard to manage during the division of learning groups, some students were calm, shy and inactive during the course of discussion. Some students failed to grasp the material regarding the presentation of data in bar charts. The average score and learning passing rate according to Cycle I test result had not reached the determined minimum success indicator of passing grade of $70 \%$, in the discussion of data presentation in bar chart.

During research observation, the researchers drew conclusion that the implementation in Cycle I was not successful yet, hence an improvement was needed to enhance result in Cycle II.

\section{$2.2 \quad$ Cycle II}

Second Cycle was conducted with three meetings on April $28^{\text {th }}$, April $30^{\text {th }}$ and May $1^{\text {st }}$ of 2018. The process in the cycle is described as follow:

In the planning [9] stage of cycle II, the researchers first developed a lesson plan regarding the material of presenting data in bar charts and processing data, prepared the material and learning sources related to the concepts in the discussion, developed exercise for final test in Cycle II, arranging student observation sheets during the learning process and used the surrounding environment such as chairs, tables, windows and doors available in the classroom.

In the stage of implementation [10], the researchers explained the material regarding data presentation in bar charts and data processing regarding determining mode, median, and average values. The researchers then asked students to observe objects in the classrooms such as tables, chairs, whiteboard, windows and doors. After the observation, students were asked to take data of the total numbers of chair, whiteboard, windows and doors in classroom. The average score of 
student learning result was 81 , with 33 students passing the minimum score and the passing rate of $92 \%$. On the other hand, 3 students failed, representing $8 \%$ of the class.

Observation of students' learning activity in Cycle 2 is described as follow:

$83 \%$ of students actively asked questions regarding the topic of discussion and answered the questions given. On the other hand, students who behaved well comprised of $78 \%$ of class; and students who interacted well with classmates and teacher represented $80 \%$ of class; and $81 \%$ of total students accurately solved the questions given by the teacher.

According to the description of Cycle II, the result can be described as follow: There were still rowdy students during the class. Average score and passing rate in cycle II had reached the success indicator. However, the researchers continued to Cycle III to figure out the consistency of students' learning results in the next cycle.

\subsection{Cycle III}

The third cycle was conducted with three meetings on April $11^{\text {th }}$, April $14^{\text {th }}$ and April $15^{\text {th }}$ of 2018. The process in Cycle III is described as follow:

In the planning stage, the researcher developed a Lesson Plan regarding the discussion of data processing involving how to determine average, mode and median values; prepared material and sources of learning related to the concepts in discussion; developing exercise for final test of student learning result in cycle III; and made student observation sheet during the classroom learning process.

In implementation [11] stage, the researchers explained about data processing regarding how to determine mode, median and average values. Then, the researchers asked the students to take the data of students' ages in the classroom of IVA, and then the students were asked to analyze the data and organize it into a table. After the table was made, the researchers distributed the students' observation sheets containing cloze test, and then the researchers asked students to understand the exercise they were about to do.

At the end of cycle III, the researchers distributed the final test exercise to students. The obtained learning result test average score in cycle III was 86 , with 34 students passing the required minimum score, representing $94 \%$ of the class. On the other hand, 2 students failed, representing $6 \%$ of the class.

The result of observation in cycle III is described as follow: Students who paid good attention when the researchers gave the explanation during the class represented $88 \%$ of all students in the classroom; students who actively asked questions during the class, such as asking about the material, comprised of $98 \%$ of all students in the classroom; Students with good behavior during the class constituted $84 \%$ of the class; students with good interaction with other students and teacher comprised of $83 \%$ of class; and students who precisely answered the questions given by teacher comprised of $83 \%$ of total students.

According to the data description in Cycle III, the result can be described as follow: The observation in Cycle III showed that the learning process of Mathematics had run well. Students' attention, activeness, behavior and interaction with their teacher and students, and understanding of material showed good results. The results of Mathematics learning about data and chart in Cycle III had reached a very good criterion, with the passing rate of $94 \%$ and average score of 86 . 
Therefore, the researchers drew a conclusion that the Classroom Action Research in Cycle III had reached a successful result, and therefore the researchers finished the result at Cycle III.

According to the results of the research, by implementing a model of Realistic Mathematic Education, there were improvements of students' learning results in every cycle[12]. The following chart displays the recapitulation of passing scores of students' learning results from Cycle I, Cycle II and Cycle III:

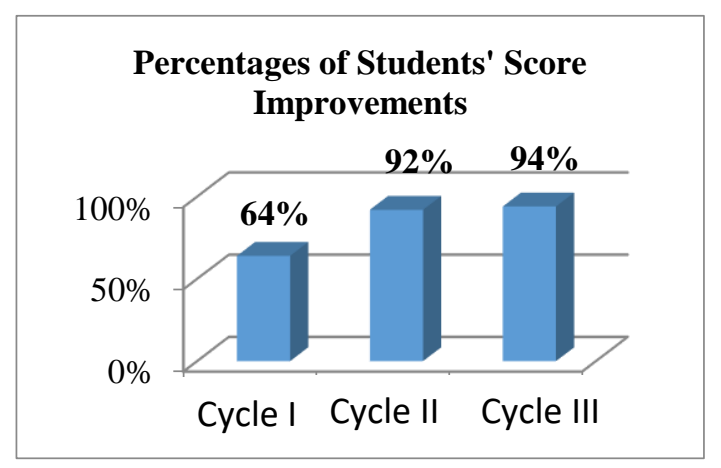

Figure of recapitulation of students' learning result passing rate

\section{Conclusion}

According to the Classroom Action Research conducted in 3 cycles, it can be concluded as follow:

First, the implementation of Realistic Mathematic Education (RME) model was proven to be effective in increasing the learning results of students, which can be seen in improvements in every cycle as follow: in cycle I, the researchers obtained an average score of 70 and the passing rate of 64\%; while in Cycle II, the researchers obtained the average score of 81 and passing rate of $92 \%$. On the other hand, in Cycle III, the researchers obtained the average score of 86 , and passing rate of $94 \%$.

Second, the application of Realistic Mathematic Education (RME) could also improve the learning activities of students. The detailed result on the aspect of students' attention in Cycle I was $74 \%$, In Cycle II improved to $82 \%$ and in Cycle III improved to $88 \%$. The following aspect was the students' activeness, with a percentage of $71 \%$ in Cycle I, in the Cycle II increased to $83 \%$, and in the Cycle III improved to $98 \%$. On the aspect of students' behavior, the Cycle I yielded the score of $73 \%$. In the Cycle II increased to $76 \%$ and in the Cycle III further improved to $84 \%$. On the aspect of students' interactions, the result in Cycle I was 70\%, in Cycle II improved to $80 \%$, and in Cycle III improved to $83 \%$. On the aspect of students' accuracy on solving he exercise, the score in Cycle I was 68\%, in Cycle II improved to 81\%, and in Cycle III improved to $83 \%$. 


\section{References}

[1] S. Muhibbin, Psikologi Pendidikan Dengan Pendekatan Baru. Bandung: PT Remaja Rosda Karya, 2014.

[2] S. Ahmad, Toeri Belajar dan Pembelajaran. Jakarta: Prenadamedia Group, 2013.

[3] D. Susanti, "Model Pembelajaran RME (Realistics Mathematic Education) Untuk Meningkatkan Hasil Belajar Matematika Tentang Konsep Pecahan Siswa Kelas Iv Sd Negeri Krapyak 2 Tahun Pelajaran 2011/2012," Kalam Cendekia Pgsd Kebumen, vol. 2, no. 4, 2014.

[4] S. Nana, Penilaiaan Hasil Proses Belajar Mengajar. Bandung: PT Remaja Rosda Karya, 2016.

[5] P. Cobb, Q. Zhao, and J. Visnovska, "Learning from and Adapting the Theory of Realistic Mathematics education," vol. 2, no. 1, pp. 105-124, 2008.

[6] S. Arikunto, Suhardjono, and Supardi, Penelitian Tindakan Kelas. Jakarta: Bumi Aksara, 2016.

[7] R. Muhammad and A. Sofyan, Strategi Dan Desain Pengembangan Sistem Pembelajaran. Jakarta: Prestasi Pustaka, 2013.

[8] F. Mumfarida, Wahyudi, and Joharman, "Penggunaan Pendekatan Realistic Mathematics Education (Rme) Dengan Media Konkret Dalam Peningkatan Pembelajaran Geometri Pada Siswa Kelas V Sd Negeri Jatimulyo Tahun Ajaran 2016/2017,” vol. 8, no. 3, pp. 1048-1055, 2017.

[9] W. N. Anisa, "Peningkatan kemampuan pemecahan masalah dan komunikasi matematik melalui pembelajaran pendidikan matematika realistik untuk siswa SMP Negeri di Kabupaten Garut," J. Pendidik. dan Kegur., vol. 1, no. 1, 2014.

[10] S. Sumirattana, A. Makanong, and S. Thipkong, "Using realistic mathematics education and the DAPIC problem-solving process to enhance secondary school students' mathematical literacy," Kasetsart J. Soc. Sci., vol. 38, no. 3, pp. 307-315, 2017.

[11] E. Soviawati, "Pendekatan matematika realistik (pmr) untuk meningkatkan kemampuan berfikir siswa di tingkat sekolah dasar," vol. 2, no. 2, pp. 79-85, 2011.

[12] T. Laurens, F. A. Batlolona, J. R. Batlolona, and M. Leasa, "How Does Realistic Mathematics Education (RME) Improve Students' Mathematics Cognitive Achievement?," EURASIA J. Math. Sci. Technol. Educ., vol. 14, no. 2, pp. 569-578, 2018. 